\title{
HEPATITIS “C”; FREQUENCY OF HEPATIC STEATOSIS IN NON RESPONDER PATIENTS \\ dr.sajidarain@gmail.com
}

1. MBBS, FCPS

Associate professor Department of Medicine,

LUMHS, Jamshoro, Sindh, Pakistan

2. MBBS, FCPS

Assistant professor Department of radiology

LUMHS, Jamshoro, Sindh, Pakistan

3. M.B.B.S, (M.D-II Trainee)

Department of Medicine,

LUMHS, Jamshoro, Sindh, Pakistan

Correspondence Address:

Dr. Muhammad Rafique Hingoro

$\mathrm{C} /$ of - National Medical Centre

Near National CNG Khurshid Town

Hala Naka Hyderabad

dr.sajidarain@gmail.com

Article received on:

25/04/2016

Accepted for publication:

$15 / 07 / 2016$

Received after proof reading:

$10 / 09 / 2016$

\section{INTRODUCTION}

In developing world as well as Pakistan, promising viral infections are widespread, $\mathrm{HCV}$ is one of those. It is nearly $2.2 \%$. HCV results into high rate morbidity and mortality, it is projected that presently 170 million of populace is affected by this syndroms. ${ }^{1}$ Infected populace in Pakistan is approximately $180,000,000 .^{2,3}$ Considering this huge populace, infection rates ranging from intermediate to high with disclosure to high risk factors such as deficiency of community health schooling, poverty and illiteracy, Pakistan is from extremely affected countries. HCV contamination is a factor of worldwide Public health threats dealing with most developing nations, where systems of health care are deficit in the safety measures essential to prevent the infections risks and where public consciousness regarding modes of transmission is inadequate. ${ }^{4}$ Steatosis is a general pathological variation that is observed with $\mathrm{CHCV}$-disease. In Pakistan high incidence rates of about $65.7 \%$ has been noted in HCV present. ${ }^{5}$ Different studies like Chow WC in one study observed that Steatosis is in $39 \%$ of cases that are infected with HCV. It has strong association with metabolic syndromes related to NAFLD. They additionally observed that steatosis is in the both cases with both variety of fatty liver that is with alcoholic as well as NAFLD. ${ }^{6}$ Many studies have exhibited a positive association among hepatic steatosis as well as its progression in $\mathrm{HCV}^{7,8}$ Longitudinal studies, like those by Castera and associates provide stronger data for causal association: paired hepatic biopsies within unprocessed 96 cases with HCV exhibited that steatosis worsening was related to progression of liver fibrosis. Multivariate analysis, revealed that the merely factor autonomously related to progression of fibrosis was steatosis worsening. ${ }^{9}$ A multicenter, multinational meta-analysis additionally accomplished that steatosis was autonomously related to fibrosis in cases having $\mathrm{HCV}^{7}$ Liver steatosis in cases with $\mathrm{HCV}$ disease is negatively associated to SVR to antiviral treatment 
and resistance to insulin has been concerned as a contributory factor in several studies. ${ }^{8,9}$ purpose of our study was determining incidence of steatosis among cases, non-responder of chronic HCV.

\section{MATERIALS AND METHODS}

This descriptive and cross sectional research was contains on 144 non responders patients of $\mathrm{HCV}$ treatment and was carried out at Medicine department, LUMHS, Jamshoro / Hyderabad with the period of time from 26-9-2011 to 25 August 2012. Both gender, age 18 to $50 \mathrm{yrs}$, chronic HCV non-responder cases as well as cases fit for hepatic biopsy were integrated in study. Patient with poor compliance history to IFN treatment, unfit cases or cases not willing to suffer liver biopsy, age above 50 and less than18 years, cases with co- morbid conditions history like end stage liver syndrome, hypertension and obese cases with BMI above 28 $\mathrm{kg} / \mathrm{m}^{2}$ were excluded from the study. Liver biopsy was carried out in each patient who pre-received interferon treatment for 6 months but yet positive $\mathrm{HCV}$. This was additionally examined as indicated by protocol which comprises surveillance of H.E. stained section. Grading of Inflammation was carried out as indicated by histopathological measures.

Burn classification system was applied to grade steatosis which is as under.
a. Grade $0=$ Non Involved
b. Grade-I = above $33 \%$ Involved
c. Grade-II = ranging from 33 to $66 \%$
d. Grade-III = above $66 \%$

Fibrosis grading:

a. Grade $0=$ No specific fibrosis

b. Grade-I = least fibrosis

c. Grade-II = Mild fibrosis

d. Grade-III = moderate fibrosis

e. Grade-IV = Cirrhosis

Relevant statistics was noted on a pre-planned proforma in accordance with exclusion as well as inclusion criteria and legal consent was integrated in this study. The statistics was analyzed via SPSS V.19.

\section{RESULTS}

Throughout the study interval, 144 cases with chronic HCV non-responder integrated in our study.

In this study, 115 (80.0\%) were men and 29 $(20.0 \%)$ were women, and mean age was 48.5 \pm 5.2 with the range of $18-50$ years. Table-l. \& Figure-1

\begin{tabular}{|c|c|}
\hline \multicolumn{2}{|c|}{ Age distribution } \\
\hline Mean & 48.5 years \\
\hline SD & 5.2 years \\
\hline
\end{tabular}

Table-I. Patients distribution according to age $\mathrm{n}=$ 144

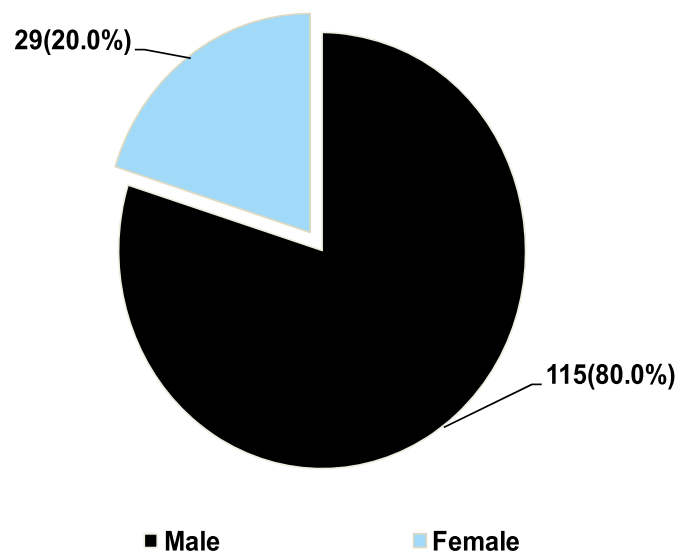

Figure-1. Patients distribution according to gender ( $n=144)$

The uppermost frequency of chronic HCV infection was observed 65(45.13\%) at the age gap from 41 to 50 years whereas $42(29.1 \%$ ) cases were noticed in 31-40 years of age group and $25(17.3 \%)$ cases were observed in $20-30$ years of age group. Table-II.

\begin{tabular}{|c|c|}
\hline Hepatic steatosis & Frequency/ \%age \\
\hline $20-30$ & $25(17.3 \%)$ \\
$31-40$ & $42(29.1 \%)$ \\
$41-50$ & $65(45.13 \%)$ \\
$<50$ & $12(8.3 \%)$ \\
\hline \multicolumn{2}{|c|}{ Table-II. Distribution of chronic HCV according to age } \\
group (n=144)
\end{tabular}




\begin{tabular}{|c|c|}
\hline Hepatic steatosis & Frequency/ \%age \\
\hline Yes & $103(71.5 \%)$ \\
No & $41(28.5 \%)$ \\
\hline
\end{tabular}

Table-iii. Distribution of hepatic steatosis according to frequency $(n=144)$

In our study liver steatosis incidence was in 103 (71.5\%) Table-III and these were marked as: grade 1 , grade 2 , grade $3,(<33 \%) 45 / 103(43.68 \%)$, (33 to $66 \%$ ) $35 / 103(33.98 \%),(>66 \%) 23 / 103(22.33 \%)$ respectively. Table-IV.

\begin{tabular}{|c|c|}
\hline Grades & Frequency/ \%age \\
\hline G-0 & $41(28.47 \%)$ \\
G-I & $45(43.68 \%)$ \\
G-II & $35(33.98 \%)$ \\
G-III & $23(22.33 \%)$ \\
\hline
\end{tabular}

Table-IV. Hepatic steatosis according to grads $(n=144)$

\section{DISCUSSION}

Examination of factors related to steatosis has been emphasized in medical literature over up to date years. The prevalence of FLD depends upon the populace scrutinized and technique applied for diagnosis. Within general populace, the incidence of FLD is $16 \%$ - $29 \%$ on ultrasonography, ${ }^{10} 31 \%-$ $34 \%$ on MRI $1,{ }^{11}$ and $15 \%-39 \%$ on liver biopsy. ${ }^{12}$ In this study overall 144 cases were integrated, out of these cases men were dominant in quantity with around $80 \%$ and women cases comprised just 20 $\%$. In these cases age group was evaluated and it exhibited that $45.13 \%$ cases were in age group of 41 to 50 years, $29.1 \%$ were 31 to 40 years of age. Uslusoy $\mathrm{HS}$ et $\mathrm{al}^{13}$ reported that 81 cases ( 40 men, 41 women) diagnosed by ultrasonographic assessment having fatty liver contributed in study at Gastroenterology Division of Uludag University.

NegroF et $\mathrm{al}^{14}$ has been quoted in a study on "Steatosis and insulin resistance in response to treatment of chronic hepatitis $C$. has described the relevance of steatosis with insulin resistance and viral treatment response". This study shows that the pathogenicity is by product of both because of viral as well as metabolic cause. This additionally detailed that viral insulin resistance because of viral disease not effected antiviral treatment however metabolic treatment has negative effect. In another research by Hwang SV et all ${ }^{15}$ stated that $\mathrm{HCV}$ and steatosis depicted that incidence of steatosis is further in individuals undergoing $\mathrm{HCV}$ disease than in general populace. These outcomes are considered in this study where most of cases with 41-50 years of age and their $\mathrm{BMI}$ were relatively higher.

In the study of Qayyuma $A$ et al $^{16}$ reported that number of patients 24 with grade 0,26 were with grade 1, 7 patients were with grade 2, and 24 cases were with grade 3 . In another study established specificity $72.9 \%$, sensitivity $71.1 \%$, NPV $82.3 \%$ and PPV $58.7 \%$ for mild steatosis diagnosis based upon ultrasound; subsequent rates for higher steatosis grades, were $60.4 \%$, $85.7 \%, 98.4 \%$ and $13 \% .{ }^{17}$ In the study of Calogero Camma et al, ${ }^{18}$ Steatosis was grade-l in 110 cases, grade-II in 46 cases, and grade-III in 9 cases. In this study, incidence of cases with steatosis was $71.5 \%$, from these cases, highest percentage of cases were with grade 1 steatosis (43.68\%). Whereas approximately $33.98 \%$ cases were with grade 2 grade 2 steatosis and approximately $22.33 \%$ were with steatosis of grade 3 .

Conjeevaram HS et all ${ }^{19}$ demonstrated that comparison of hepatic steatosis occurrence was assessed in 2 groups, $1^{\text {st }}$ group was Caucasian Americans and $2^{\text {nd }}$ group was African American. It was accomplished from this study that African American cases had higher hepatic steatosis incidence as compare to Caucasian Americans. This study moreover exposed that resistance to insulin was more possibly related to low sustained virological response as compare to hepatic steatosis. BMI relationship with steatosis has been considered by SHailkh et $\mathrm{al}^{20}$ which exhibits a significant $\mathrm{BMI}$ relationship with steatosis this is reflected in this study too.

\section{CONCLUSION}

The findings of this study shows that incidence of hepatic steatosis was quit higher in cases of chronic HCV those were non responder of hepatic treatment. Further the biopsy showed that grades 
steatosis as per Burnt grading system; grade 1 and grade 2 were more common in patients in this study. These findings of this study are required to be further investigated. Our study clearly suggested that these cases with HCV disease must be considered at earliest possible duration to prevent them from being non responder to antiviral treatment.

Copyright@ 15 July, 2016.

\section{REFERENCES}

1. Hwang SJ, Luo JC, Chu CW, et al. Hepatic steatosis in chronic hepatitis $C$ virus infection: prevalence and clinical correlation. J Gastroenterol Hepatol. 2001 Feb; 16(2):190-5.

2. Yoneda M, Fujita K, Nozaki Y, Endo H, Takahashi H, Hosono K, et al. Efficacy of ezetimibe for the treatment of non-alcoholic steatohepatitis: An open-label, pilot study. Hepatol Res. Jun 2010; 40(6):613-21.

3. Adams LA, Zein CO, Angulo P, Lindor KD. A pilot trial of pentoxifylline in nonalcoholic steatohepatitis. $A m$ J Gastroenterol. Dec 2004; 99(12):2365-8.

4. Semb S, Dam-Larsen S, Mogensen AM, Albrectsen $J$, Bendtsen F. Low incidence of non-alcoholic steatohepatitis in a Danish liver unit. Dan Med J. Jan 2012; 59(1):A4354.

5. Mirandola S, Realdon S, Iqbal J, Gerotto M, Dal Pero F, Bortoletto G, Marcolongo M,Vario A, Datz C, Hussain $\mathrm{MM}$, Alberti A: Liver microsomal triglyceride transfer protein is involved in hepatitis C liver steatosis. Gastroenterology. 2006 May; 130(6):1661-9.

6. Armstrong GL, Wasley A, Simard EP, et al. The prevalence of hepatitis $C$ virus infection in the United States, 1999 through 2002. Ann Intern Med 2006; 144:7.

7. Leandro G, Mangia A, Hui J, Fabris P, Rubbia-Brandt L, Colloredo $G$, et al. Relationship between steatosis, inflammation, and fibrosis in chronic hepatitis C: a meta-analysis of individual patient data. Gastroenterology 2006; 130:1636-42.

8. Patton HM, Patel K, Behling C, Bylund D, Blatt LM, Vallee $M$, et al. The impact of steatosis on disease progression and early and sustained treatment response in chronic hepatitis $\mathbf{C}$ patients. $\mathrm{J}$ Hepatol 2004; 40:484-90.

9. Castera L, Hezode C, Roudot-Thoraval F, Bastie A, Zafrani ES, Pawlotsky JM, et al. Worsening of steatosis is an independent factor of fibrosis progression in untreated patients with chronic hepatitis $C$ and paired liver biopsies. Gut 2003; 52:288-92.

10. Bedogni G, Miglioli L, Masutti $F$, et al. Prevalence of and risk factors for nonalcoholic fatty liver disease: the Dionysos nutrition and liver study. Hepatology. 2005; 42(1):44-52.

11. Szczepaniak L, nurenberg P, Leonard D, et al. Magnetic resonance spectroscopy to measure hepatic triglyceride content: prevalence of hepatic steatosis in the general population. Am J Physiol endocrinol Metab. 2005; 288(2):e462-8.

12. Hilden M, Christoffersen P, Juhl e, Dalgaard JB. Liver histology in a 'normal' population- -examinations of 503 consecutive fatal traffic casualties. Scand J Gastroenterol. 1977; 12(5):593-7.

13. Hüseyin Saadettin Uslusoy, Selim Giray Nak, Macit Gülten. Noninvasive predictors for liver fibrosis in patients with nonalcoholic steatohepatitis. World $\mathrm{J}$ Hepatol 2011 August 27; 3(8): 219-227.

14. Negro F,Sanyal. AJ. Hepatitis C virus, steatosis and lipid abnormalities: clinical and pathogenic data. Liver Int.2009; 2:26-37.

15. Hwang SJ, Luo JC, Chu CW, Lai CR, Lu CL, Tsay SH et al. Hepatic steatosis in chronic hepatitis $C$ virus infection: prevalence and clinical correlation. J Gastroentrol Hepatol.200; 16(2):190-37.

16. Aliya Qayyuma, ${ }^{*}$, Daryl M. Chena, Richard S. Breimana, Antonio C. Westphalena, Benjamin M. Yeha, Kirk D. Jonesb. Evaluation of diffuse liver steatosis by ultrasound, computed tomography, and magnetic resonance imaging: which modality is best? Clin Imaging. 2009; 33(2): 110-115.

17. Soresi M, Tripi S, Franco V, Giannitrapani L, Alessandri A, Rappa $F$ et al. Impact of liver steatosis on the antiviral response in the hepatitis $C$ virus-associated chronic hepatitis. Liver Int.2006; 26(9):1119-25.

18. Calogero Camma, ' 1,2 Savino Bruno, 3 Vito Di Marco, 1 Danilo Di Bona,1,2Mariagrazia Rumi,4Maria Vinci,5 Chiara Rebucci,6. Insulin Resistance Is Associated With Steatosis in Nondiabetic Patients With Genotype 1 Chronic Hepatitis C. HEPATOLOGY, Vol. 43, No. 1, 2006; 64-71.

19. Conjeevaram HS, Kleiner DE, Everhart JE, Hoofnagle $\mathrm{JH}$, Zacks S, Afdhal NH et al, Race, insulin resistance and hepatic steatosis in chronic hepatitis C. Hepatology.2007;45(1):80-7.

20. Shaikh S, Sadik M, Hussain BG. Frequency of steatosis and its relation with the grade of fibrosis in patients with hepatitis C. Pak J Med Sci 2009;25(2):283-28. 


\title{
PREVIOUS RELATED STUDY
}

Dilshad Muhammad, Khalid Amin, Amin Anjum, Masood Javed. CHRONIC HEPATITIS C VIRUS INFECTION; ASSOCIATION WITH TYPE 2 DIABETES MELLITUS (Original) Prof Med Jour 17(4) 557-562 Oct, Nov, Dec 2010.

Fatima Mehboob, Zafar Majeed Babar. HEPATITIS C PATIENTS; TREATMENT COMPLIANCE OF HAVING POOR SOCIOECONOMIC BACK GROUND (Original) Prof Med Jour 15(1) 61 - 66 Jan, Feb, Mar, 2008.

Faqir Muhammad Tariq, Habib Subhani, Irshad Ahmad, Irshad ul Haq. HEPATITIS C; PREVALENCE IN PARAMEDICAL STAFF OF A TEACHING HOSPITAL(Original) Prof Med Jour 16(2) 168-172 Apr, May, Jun, 2009.

Muhammad Afzal, Irfan Ahmed Mughal, Naushen Afzal, Muhammad Badar Bashir, Fiyaz Ahmed Malik. CHRONIC HEPATITIS C INFECTION; CORRELATION OF GLUCOSE TOLERANCE TEST, THE LEVELS OF FASTING BLOOD SUGAR (FBS) AND HEMOGLOBIN (Original) Prof Med Jour 11(2) 222-227 Apr, May, Jun, 2004.

Muhammad Naeem, Ameer Ahmad, Imran Qaisar, Fiaz Ahmad. STATUS OF HEPATITIS C VIRUS (HCV) NFECTIONS; CHILDREN ADMITTED IN PEDIATRIC WARD OF BAHAWAL VICTORIA HOSPITAL BAHAWALPUR (Original) Prof Med Jour 18(3) 445-449 Jul, Aug, Sep 2011.

Nuzhat Parveen Khawaja, Uzma Hussain, Farzana Latif, Rakhshanda Reman. RISK FACTORS FOR HEPATITIS C VIRUS; OBSTETRICS PATIENTS. (Original) Prof Med Jour 16(3) 428-431 Jul, Aug, Sep, 2009.

S. M. Abbas Naqvi, Qurban ali Khaskheli, Shahid Habib Ansari, Muhammad Shiraz Khan, Muhammad Saeed Talpur. HEPATITIS C VIRUS; PREVALENCE IN BLOOD DONORS IN KARACHI (Original) Prof Med Jour 13(4) 604- 07 Oct, Nov, Dec, 2006.

Shaukat Ali, Syed Khurram Shahzad, Atiq ur Rehman Slehria. CHRONIC HEPATITIS C; RESPONSE TO INTERFERON AND RIBAVIRIN COMBINATION (Original) Prof Med Jour 17(4) 563-567 Oct, Nov, Dec 2010.

Waheed Ahmed, Manzar Zakaria, Syed Badshah Hussain Zaidi. HEPATITIS C; FREQUENCY OF THROMBOCYTOPENIA PATIENTS TREATED WITH INTERFERON (Original) Prof Med Jour 17(1) 117-121 Jan, Feb, Mar 2010.

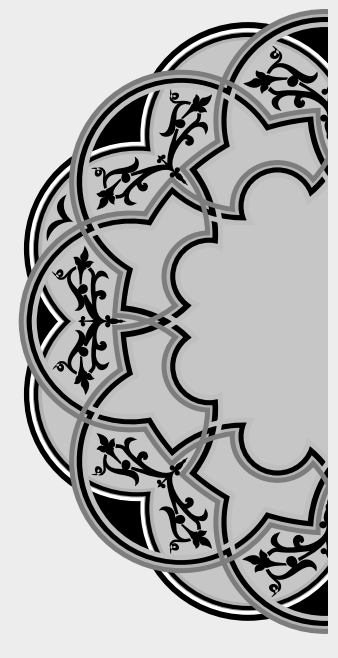

\section{"Don't look back - you're not going that way."}

\author{
Unknown
}

\section{AUTHORSHIP AND CONTRIBUTION DECLARATION}

\begin{tabular}{|c|l|l|l|}
\hline Sr. \# & \multicolumn{1}{|c|}{ Author-s Full Name } & \multicolumn{1}{|c|}{ Contribution to the paper } & Author=s Signature \\
\hline 1 & Dr. Muhammad lqbal & 1st Author & \\
2 & Dr. Adnan Ahmed & 2nd Author \\
3 & Dr. M. Rafique Hingoro & 3rd Author & \\
\hline
\end{tabular}

